\title{
Stress Mediation in the Effect of Work-Family Conflict on Job Satisfaction of Women Bamboo Craftsmen
}

\author{
Ni Made Dwi Ariani Mayasari $1{ }^{1,}$ Komang Krisna Heryanda ${ }^{1}$ Wayan Sayang \\ Telagawathi ${ }^{1}$ Nengah Suarmanayasa ${ }^{1}$
}

\author{
${ }^{1}$ Department of Management, Universitas Pendidikan Ganesha, Singaraja, Indonesia \\ *Corresponding author. Email: dwi.mayasari@undiksha.ac.id
}

\begin{abstract}
This study looked on the employment satisfaction of women bamboo crafters in Sidatapa Village. The dependent variable was the employment satisfaction of women bamboo craftsmen in Sidatapa village. Using questionnaires and in-depth interviews, data was collected. The investigation used path analysis with work stress as a mediating variable. Work-family conflict and stress had a direct impact on job satisfaction of women bamboo craftsmen in Sidatapa village. The results showed that less work stress mediated the effect of family work conflict on job satisfaction of female bamboo craftsmen in Sidatapa village.
\end{abstract}

Keywords: Job Satisfaction, Stress, Work-Family Conflict.

\section{INTRODUCTION}

Participation in the workfield also really requires women to help increase family income, especially for lower-middle families for family welfare. Women work either as bamboo craftsmen, garden/rice field farmers, farm laborers, and market sellers, aiming to fulfill the needs of their household life. Moreover, if her husband who works as the breadwinner for the family is not able to meet their daily needs. The traditional rules that view women as having to stay at home and take care of all the needs of the family around the house are now slowly being abandoned. This shift in view is realistically in line with social changes that are increasingly demanding hard work. Even in the village, the patriarchal culture that makes men "kings" is starting to be abandoned. The women work to support the family's economy. The contextual work of women is still within the normal limits of being feminine, in the sense that women who work do not come out of their nature in society. Although women work only as the rib of the family, women also need job satisfaction so that the work carried out is in accordance with their expectations.

Job satisfaction is a pleasant response to a job. Levy [1] states that the factors that influence job satisfaction are job characteristics, individual characteristics, social factors, and work-family conflict. In addition, Elizabeth [2] states Work-family conflict can increase work stress, which causes job dissatisfaction. In line with Bagia [3] that work stress is triggered by stressors outside of work which include indicators of work-family conflict and can cause job dissatisfaction. Also, research from Ardita [1] and Astari [4] showed that occupational stress negatively impacts job satisfaction through job stress.

During a pandemic like this, job satisfaction experienced by female workers is decreasing. One of them is caused by the decreasing income received, even though in some households the income of working women contributes to the family's economy. As happened to the bamboo craftsmen in Sidatapa village, many women work as bamboo craftsmen to supplement the family's income. Several women craftsmen complained about the declining income they received due to delays in the delivery of handicrafts as a result of activity restrictions by the government. Delivery of handicrafts outside the region becomes difficult. In addition, the declining demand for bamboo handicrafts causes a decrease in income received.

The decrease in job satisfaction of women bamboo craftsmen in Sidatapa village is also caused by the dual roles that they must carry out. This dual role triggers a high level of work-family conflict. Work-family conflict is a role conflict that occurs because of an imbalance in the implementation of roles in work and family [5]. Work-family conflict also causes work stress on employees. Haholongan \& Kusdinar [6] stated that work-family conflict is the main source of work stress. In addition, Bagia [3] also states that stress can be caused by stressors outside of work which include indicators of work-family conflict, and have an impact on a person's psyche, namely job dissatisfaction and 
depression. Depression that leads to stress affects a person's psychology, such as job satisfaction. Work stress can be influenced by several things such as workload and work climate [7].

Work-family conflict is a role conflict that occurs because of an imbalance in the implementation of roles in work and family [8]. On the one hand, women must carry out their obligations as housewives, while on the other hand they must work to help the family economy. The current imbalance is partly due to reduced working hours due to declining demand for bamboo crafts, so that the income earned is decreasing. The decrease in the income earned by these women bamboo craftsmen has also led to a decline in family welfare. This condition is exacerbated by the decline in the husband's income as the head of the family who also mostly works as a bamboo craftsman.

The decrease in job satisfaction that occurred in women bamboo craftsmen in Sidatapa village was also caused by higher stress levels. Stress affects a person's psychology, such as on job satisfaction [9]. Women who have a dual role, namely as housewives who have to take care of the family and as workers certainly have higher stress levels than men. The high stress is understandable considering that most of these women bamboo craftsmen are very dependent on this work. Most of these women bamboo craftsmen do not have skills in other fields, so they are very dependent on the trade in the bamboo handicrafts that they produce.

Sidatapa Village is one of the original villages in Bali which is known as Bali Mula. The existence of women in the Sidatapa village community is recognized as equal to men. Women play an important role in every activity of the Sidatapa village community. The important role of women in Sidatapa society is highly respected. This perceived equality causes the women of Sidatapa village take part not only in traditional and religious activities, but also in family economic activities. Many women in Sidatapa village work to help the family's economy. For this reason, it is very important to pay attention to the psychological aspects concerning women who work so that family harmonization can be realized both economically and socially.

Based on the previous explanation, it can be summarized and formulated problems, including whether work-family conflict affects the job satisfaction of women bamboo craftsmen in Sidatapa village, whether stress affects job satisfaction of women bamboo craftsmen in Sidatapa village, and whether work stress is able to mediate the outcome of household conflict on job satisfaction of bamboo craftsmen in Sidatapa village

\section{METHOD}

This study used quantitative methods with the research design used is causal, namely research on cause and effect [10]. The populations in this study were 71 married women bamboo craftsmen in Sidatapa village. All populations were used as respondents in this study. The technique used for data collection was in the form of a questionnaire/questionnaire. Questionnaires are used to collect data by asking respondents to answer questions or written comments [11]

The indicator's ability to produce latent variables is tested using the validity test. With respect to the convergent validity test, each indicator's outer loading value must be $>0.7$, while the discriminant validity test requires each indicator's cross loading value to be $>0.7$. (Jogiyanto, 2015). The reliability test determines a model's consistency and measurement accuracy. It is dependable if the composite reliability value is $>0.7$. (Jogiyanto, 2015).

This study employed path analysis to analyze data since there was a correlation between exogenous factors. This study examined the impact of work-family conflict (X1) and work stress (X2) on job satisfaction (Y). Also, the impact of work-family conflict (X1) and (X2) on job satisfaction (Y).

\section{RESULTS \& DISCUSSION}

Based on the results of data analysis, the results of the research instrument test, namely validity and reliability tests, it was found that the Cronbach's Alpha value of all variables, both $\mathrm{X}_{1}$ (work-family conflict), $\mathrm{X}_{2}$ (work stress), and $Y$ (job satisfaction) all values $>0.7$ which meant all research variables were reliable. The Average Variance Extracted (AVE) value of all variables was $>0.5$, which meant that all research variables were valid. The results of the multi-co linearity test stated that all indicators of the research variables had a VIF value of $<0.5$, which meant they were free from multi-co linearity.

The direct influence of work-family conflict variables on job satisfaction and stress on job satisfaction can be seen in the following table.

Table 1. The direct influence of work-family conflict variables on job satisfaction and stress on job satisfaction

\begin{tabular}{|l|c|c|r|r|r|}
\hline & $\begin{array}{c}\text { Original } \\
\text { Sample } \\
(\mathrm{O})\end{array}$ & $\begin{array}{c}\text { Sample } \\
\text { Mean } \\
(\mathrm{M})\end{array}$ & $\begin{array}{c}\text { Standard } \\
\text { Deviation } \\
\text { (STDEV) }\end{array}$ & $\begin{array}{c}\text { T Statistics } \\
\text { (IO/STDEVI) }\end{array}$ & $\begin{array}{c}\mathrm{P} \\
\text { Values }\end{array}$ \\
\hline $\mathrm{X} 1->\mathrm{X} 2$ & 0,839 & 0,845 & 0,034 & 24,789 & 0,000 \\
\hline $\mathrm{X} 1->\mathrm{Y}$ & $-0,443$ & $-0,441$ & 0,113 & $-3,918$ & 0,012 \\
\hline $\mathrm{X} 2->\mathrm{Y}$ & $-0,518$ & $-0,521$ & 0,112 & $-4,636$ & 0,002 \\
\hline
\end{tabular}


Work-family conflict (X1) has a favorable and significant effect on stress (X2) for women bamboo crafters in Sidatapa village. The stress level of women bamboo crafters in Sidatapa village increases with work-family conflict. Job satisfaction (Y) is -0.443 with a p-value of 0.0120 .05 for women bamboo artisans in Sidatapa village. Women bamboo crafters in Sidatapa village report decreasing job satisfaction as work-family conflicts increase. The direct effect of stress (X2) on job satisfaction $(\mathrm{Y})$ was -0.518 with a p-value of 0.0020 .05 . Stress reduces the employment satisfaction of women bamboo crafters in Sidatapa village. The more stressed women bamboo craftsmen in Sidatapa village, the less satisfied they are.

Path analysis test (path analysis) of the work-family conflict variable $\left(\mathrm{X}_{1}\right)$ on job satisfaction $(\mathrm{Y})$ through stress $\left(\mathrm{X}_{2}\right)$ can be seen in the following table.

Table 2. Path Analysis Test

\begin{tabular}{|c|c|c|c|c|}
\hline & $\begin{array}{l}\text { Original } \\
\text { Sample } \\
(0)\end{array}$ & $\begin{array}{c}\text { Sample } \\
\text { Mean } \\
\text { (M) }\end{array}$ & \begin{tabular}{|l|} 
Standard \\
Deviation \\
(STDEV) \\
\end{tabular} & \begin{tabular}{|c|c|}
$\begin{array}{c}\text { T Statistics } \\
\text { (IO/STDEVI) Values }\end{array}$ \\
\end{tabular} \\
\hline $\begin{array}{ll}X 1 & -> \\
X 2 & ->Y\end{array}$ & $-0,435$ & $-0,440$ & 0,097 & \begin{tabular}{l|l}
$-4,475$ & 0,000
\end{tabular} \\
\hline
\end{tabular}

In the table, it can be seen that the coefficient of the indirect effect of work-family conflict (X1) on job satisfaction $(\mathrm{Y})$ through stress $(\mathrm{X} 2)$ is -0.435 with a $\mathrm{p}$ value of $0.000<0.05$, which means that stress is able to mediate the effect of work-family conflict. family on job satisfaction. The higher the work-family conflict causes stress and results in job satisfaction of women bamboo craftsmen in Sidatapa village.

The results showed that the higher the work-family conflict, the higher the stress experienced. The positive influence of work-family conflict on work stress was supported by the theory of Roolinson [12] that one of the causes of work stress is the work environment which includes deviations that occur between work and family. It was also supported by the research results of Ardita et al. [1] and Astari [4] that work-family conflict has a significant positive effect on work stress. That is, the higher the conflict that occurs between work and family can cause an increase in one's work stress.

The majority of respondents were women who were married and had children. This certainly caused an increase in perceived role conflict which could cause disruption of emotional stability at work, which could lead to an increase in work stress. The amount of work required of women craftsmen caused them to feel overwhelmed in their jobs as housewives. Completion of work that often exceeded working hours caused the abandonment of work as a housewife. This triggers conflict both at work and in the family caused higher stress. Therefore, efforts were needed in dealing with work stress caused by work-family conflicts to minimize the negative impacts that will be caused, such as controlling physical stress through exercise, fostering good social relationships with coworkers and family, and creating a comfortable work environment. Because with good social support with colleagues, family and supported by a comfortable work environment, medical personnel would feel cared for so that stress and conflict could be resolved.

The finding shows that work-family conflict had a negative and significant effect on job satisfaction of women bamboo craftsmen in Sidatapa village. The workforce is less satisfied with their jobs if they perceive work-family conflict. The results of this study supported the theory of Luthans [7] that intra-individual conflict which included role conflict and ambiguity can cause psychological problems such as mood changes, low self-esteem, and job dissatisfaction. Meanwhile, an empirical study that supported the results of this study was a study conducted by Rajak [13] that the higher the work-family conflict, the lower one's job satisfaction. In addition, the results of research from Piko [14] and Conant [15] also showed that job dissatisfaction is caused by the high perceived work-family conflict.

The existence of work-family conflicts that can cause job dissatisfaction among women bamboo craftsmen in Sidatapa village was supported by the characteristics of the respondents, namely the married women. This of course can trigger conflicts between work and family because in addition to having to focus on work, they also had to carry out the role of housewives with many tasks. Work-family conflicts also occured due to family pressure on the work they have, such as family concerns about the work risks faced especially during the current Covid-19 pandemic season. This caused mental stress in working between carrying out work duties and maintaining family safety and health. This condition would lead to less than optimal implementation of roles both in work and family, so that it would reduce job satisfaction.

Further research demonstrates that work stress negatively impacts the job satisfaction of female bamboo craftsmen. The findings of this study supports the theory of Luthans [7] and Robbins [16] that the impact of high work stress on a person's psychology is to reduce job satisfaction. Meanwhile, empirical studies that support this research are the results of research conducted by Ariana [17] and Ardita et al. [1] that high work stress can reduce one's job satisfaction. It is also reinforced by the research results of Sutardi, et al. [18] that job stress has a detrimental impact on job satisfaction. This suggests that the more a person's workplace stress, the worse his job happiness.

Based on further observations, the main trigger of stress for women bamboo craftsmen in Sidatapa village 
was caused by the high workload at certain times. The number of orders that must be completed immediately caused an increase in the work time that must be devoted to completing the work. As a result, her job as a housewife was neglected. In addition, social work in the community such as traditional ceremonies also demanded high participation from women. This caused women to be smart in dividing their time so that they can carry out various burdensome roles.

Work-family conflict mediated the effect of worklife stress on job satisfaction of women bamboo craftsmen in Sidatapa. According to Bagia [3] and Darmawati [19], stress is induced by external stressors such as work-family conflict indicators including timebased conflict, strain-based conflict, and behavior-based conflict, which can influence a person's psyche and lead to job dissatisfaction, depression, etc. Yani's [20] research shows that work-family conflict and stress have a considerable detrimental effect on job satisfaction. Furthermore, Astari [4] found that work-family conflict negatively impacts job satisfaction by causing work stress.

The conflicts that occur in the household and family lives of women bamboo craftsmen in Sidatapa village were quite diverse. The responsibility as a woman who has to give birth to children, take care of the household, socialize in the community and work to help the family economy often caused problems both in the family and in the work environment. It is in line with the statement that, demands on women cause high stress experienced. Being overwhelmed in dividing time between work, taking care of family and social activities in the community caused psychological pressure that leads to stress. As a result of this situation, the job satisfaction of women bamboo craftsmen in Sidatapa village was decreasing.

\section{CONCLUSION}

Work-family conflict had a favorable and significant effect on the stress of women bamboo crafters in Sidatapa, the study concluded. Work-family conflict and stress impacted the job satisfaction of women bamboo craftsmen in Sidatapa. Work-family conflict mediated the effect of stress on job satisfaction of women bamboo craftsmen in Sidatapa village.

Overcoming conflicts that occur both in the work environment and in the family environment are suggested to be managed properly. Better communication with coworkers and family members can help reduce conflict. The division of work time and time to take care of the household strictly so that work can go according to plan without disturbing the time to take care of the household can reduce the level of stress experienced. Stress can also be overcome by doing activities with colleagues and family outside of working hours. This can eliminate the workload and the burden of taking care of the household temporarily so that it can reduce the stress experienced.

\section{REFERENCES}

[1] Q. T. Ardita, Agusdin, and L. M. Furkan, "Analisis Pengaruh Konflik Pekerjaan-Keluarga (WorkFamily Conflict) Dan Stres Terhadap Kepuasan Kerja Pada Karyawan Wanita Di Sekretaris Daerah (Setda) Kabupaten Di Pulau Lombok," J. Magister Manaj. Univ., vol. 7, no. 3, pp. 29-44, 2018.

[2] Elizabeth, "Peran Ganda Wanita Tani dalam Mencapai Ketahanan Pangan Rumah Tangga di Pedesaan," J. Iptek Tanam. Pangan, vol. 3, no. 1, pp. 59-68, 2008.

[3] W. Bagia, Perilaku Organisasi. Yogyakarta: Graha Ilmu, 2015.

[4] M. Astari and A. Sudibya, "Pengaruh Work-Family Conflict terhadap Stres dan Kepuasan Kerja," EJurnal Manaj. Unud, vol. 7, no. 7, pp. 1895-1926, 2018.

[5] M. Busro, Teori-teori Manajemen Sumber Daya Manusia. Jakarta: Prenadamedia Grup, 2018.

[6] Haholongan and Kusdinar, "The Influence of Role Conflict and Role Overload to Job Satisfaction," J. Adv. Econ. Bus. Manag. Res., vol. 132, pp. 89-92, 2019.

[7] F. Luthans, Perilaku Organisasi, (Alih Bahasa V.A Yuwono, dkk), Edisi Bahasa Indonesia. Yogyakarta: ANDI, 2006.

[8] Christy and Yan, "Work Family Conflict dan Subjective Well-Being pada Polisi Wanita," $J$. Humanit., vol. 4, no. 1, pp. 14-21, 2020.

[9] B. Mocheche and Raburu, "Influence of SelfEsteem on Job Satisfaction of Secondary School Teachers in Kenya," Int. J. Adv. Multidiscip. Soc. Sci., vol. 3, no. 2, pp. 29-39, 2017.

[10] S. Siyoto and A. Sodik, Dasar Metodologi Penelitian. Yogyakarta: Literasi Media Publishing, 2015.

[11] Sugiyono, Metodologi Penelitian Manajemen. Bandung: CV. Alfabeta, 2014.

[12] D. Rollinson, Organisational Behaviour and Analysis. London: Ashford Colour Press, 2002.

[13] A. Rajak, "Pengaruh Konflik Interpersonal, WorkFamily Conflict dan Stres, Terhadap Kepuasan Kerja dan Dampaknya Terhadap Kepuasan Hidup," J. Siasat Bisnis., vol. 17, no. 2, pp. 130-156, 2013. 
[14] B. Piko, "Burnout, Role Conflict, Job Satisfaction And Psychosocial Health Among Hungarian Health Care Staff: A Questionnaire Survey," Int. J. Nurs. Stud., vol. 4, no. 3, pp. 311-318, 2006.

[15] E. B. Conant, "The Impact of Role Conflict on Job Satisfaction of Independent School Athletic Directors," J. Amat. Sport, vol. 3, no. 1, pp. 1-25, 2017.

[16] S. Robbins and Judge, Perilaku Organisasi. Jakarta: Salemba Empat, 2013.

[17] I. W. J. Ariana and I. G. Riana, "Pengaruh WorkFamily Conflict Dan Stres Kerja Terhadap Kepuasan Kerja Karyawan," E-Jurnal Manaj. Unud, vol. 5, no. 7, pp. 4630-4659, 2016.

[18] D. Sutardi, "Pengaruh Work-Family Conflict, Stres Kerja dan SocialvSupport terhadap Kepuasan Kerja: Studi Kasus pada Guru Wanita di Tanggeran," EduPsyCouns J., vol. 2, no. 1, pp. 482-498, 2020.

[19] Darmawati, Work Family Conflict Konflik ( Peran Pekerjaan Dan Keluarga). Pare-Pare: Iain Parepare Nusantara Press, 2019.

[20] N. W. Yani, I. G. A. Sudibya, and A. G. Rahyuda, "Pengaruh Work-Family Conflict dan Stres Kerja Terhadap Kepuasan Kerja dan Turnover Intention Karyawan Wanita," E-JurnalEkonomi dan Bisnis Univ. Udayana, vol. 5, no. 3, pp. 629-658, 2016. 